\title{
O moderno no progresso de uma cultura urbana, escolar e religiosa na constituição de um município mineiro
}

The modern in the progress of an urban, scholastic and religious culture in the constitution of a mining municipality

El moderno en el progreso de una cultura urbana, escolar y religiosa en la constitución de un municipio minero

Jardel Costa Pereira ${ }^{1}$

\section{Resumo}

Este artigo tem como objetivo analisar o desenvolvimento urbano e educacional com base em categorias classificadas como "moderno" e de "progresso". Tomando como referência a cidade de Lavras, localizada no sul do Estado de Minas Gerais e os seus acervos documentais, pretende-se demonstrar como o poder público municipal participou no surgimento de importantes instituições, entre elas a educacional. Por meio de uma pesquisa históricodocumental, demonstrou-se como a construção do urbano se tornou um fator importante na cidade de Lavras, sendo um indicativo de que a preocupação com a ordem social estava aliada à questão do progresso, bem como se defendeu a hipótese de que a instalação de escolas não foi um fator imediato e fundamental para o surgimento das vilas. Após a elevação da vila à cidade, o poder municipal estendeu a preocupação às questões sociais e educacionais, com a participação de uma elite modernista de intelectuais e educadores.

Palavras-chave: História da Educação; Municipalidade; Cultura Urbana.

\footnotetext{
${ }^{1}$ Doutorado em Educação Escolar pela Universidade Estadual Paulista Júlio de Mesquita Filho, com estágio de pesquisa na Loyola University Chicago (Estados Unidos). Professor da Universidade do Estado de Minas Gerais (Leopoldina). E-mail: jardelcostper@gmail.com
} 


\begin{abstract}
This article aims to analyze urban and educational development based on categories classified as "modern" and "progress". Taking as reference the city of Lavras, located in the south of the State of Minas Gerais and its documentary collections, it intends to demonstrate how the municipal public power participated in the emergence of important institutions, among them the educational one. Through a historical-documentary research, it was demonstrated how the construction of the urban became an important factor in the city of Lavras, being an indication that the concern with the social order was allied to the question of progress, and defended the hypothesis that the installation of schools was not an immediate and fundamental factor for the emergence of the villages. After the elevation of the village to the city, the municipal power extended the preoccupation to the social and educational questions, with the participation of a modernist elite of intellectuals and educators.
\end{abstract}

Keywords: History of Education; Municipality; Urban Culture.

\title{
Resumen
}

Este artículo tiene como objetivo analizar el desarrollo urbano y educativo en base a categorías clasificadas como "modernas" y de "progreso". Tomando como referencia la ciudad de Lavras, ubicada en el sur del Estado de Minas Gerais y sus acervos documentales, se pretende demostrar cómo el poder público municipal participó en el surgimiento de importantes instituciones, entre ellas la educativa. Por medio de una investigación históricodocumental, se demostró cómo la construcción del urbano se tornó un factor importante en la ciudad de Lavras, siendo un indicativo de que la preocupación con el orden social estaba aliada a la cuestión del progreso, así como se defendió la hipótesis de que la instalación de escuelas no fue un factor inmediato y fundamental para el surgimiento de las villas. Después de la elevación de la villa a la ciudad, el poder municipal extendió la preocupación a las cuestiones sociales y educativas, con la participación de una élite modernista de intelectuales y educadores.

Palabras clave: Historia de la Educación; municipio; Cultura Urbana. 


\section{Noções de progresso e civilização nos periódicos lavrenses do final do século XVIII e início do XX}

Neste artigo $^{2}$, a noção de moderno é tratada como transformações econômicas, políticas e sociais que perpassam os séculos XVIII e XIX. A pesquisa concentra-se em dados ocorridos antes e a partir da Proclamação da República, em 1889, e estende-se às primeiras décadas do século XX, período em que também se desenvolveu um dos mais expressivos movimentos de modernização da educação pública primária brasileira.

O conceito de moderno aqui delineado é construído, inserido e pautado pelo desenvolvimento urbano de uma cidade do interior mineiro, no período de exploração aurífera, quando várias cidades interioranas passaram a imprimir outra organização com a ocupação espacial. Os indicativos dessa transformação, ou de uma necessidade de modernização, foram relatados na imprensa da cidade de Lavras, quando vários escritores, por meio de notícias publicadas na imprensa local, aspiraram ao moderno, expresso principalmente, na palavra progresso, ou quando criaram instituições que remetem ao conceito de moderno.

Acompanhar o surgimento da imprensa escrita ${ }^{3}$ na cidade de Lavras faz-se necessário para compreender o momento em que as notícias surgiram, quando as campanhas a favor da libertação dos escravos estavam acirradas no país, como também o movimento a favor do regime republicano, que se fortalecia. Portanto, a data do primeiro jornal lavrense de que se tem conhecimento é 1887, um ano anterior à Lei Áurea e dois anos que antecedem a Proclamação da República. Percebe-se, nessa época, o surgimento expressivo de jornais, como também a ausência deles no período em que se inicia a Ditadura Militar no século XX. Nesse contexto, o jornal A Gazeta marcou uma existência de 37 anos de cobertura jornalística.

Quadro 1 - Relação dos jornais existentes na cidade de Lavras-MG de 1887 a 1967

\begin{tabular}{|l|l|}
\hline Ano & \multicolumn{1}{|c|}{ Jornal } \\
\hline 1887 & Jornal Lavrense \\
\hline 1887 & A Flor \\
\hline 1888 & Gazeta de Lavras \\
\hline 1889 & O Rio Grande \\
\hline 1891 & O Trabalho \\
\hline 1891 & O Lar \\
\hline 1893 & Folha de Lavras \\
\hline 1894 & O Caracter \\
\hline 1894 & O Correio de Lavras \\
\hline 1895 & O Leque \\
\hline 1895 & A Espada \\
\hline 1895 & O Púlpito Evangélico \\
\hline 1895 & Cidade de Lavras \\
\hline 1897 & Gazeta de Lavras (2. ${ }^{\text {a }}$ fase) \\
\hline
\end{tabular}

\footnotetext{
${ }^{2}$ Este artigo está fundamentado num dos capítulos de minha tese de doutorado, defendida na Universidade Estadual Paulista, Campus Araraquara, no ano de 2014, sob a orientação da professora Rosa Fátima de Souza Chaloba, com o financiamento da CAPES.

${ }^{3}$ Até 1808 , a imprensa escrita no país sofreu severa censura, sendo que somente após a vinda da Família Real para o Brasil é que circulou o primeiro jornal impresso com informações sobre a Corte Portuguesa instalada na cidade do Rio de Janeiro. Somente a partir de 1821 é que foi proclamada a liberdade de imprensa, mas anteriormente a isso já circulavam no Brasil vários jornais de oposição, como o Correio Braziliense, que era impresso em Londres (VILELA, 2007, p. 422).
} 


\begin{tabular}{|l|l|}
\hline Ano & \multicolumn{1}{|c|}{ Jornal } \\
\hline 1898 & O Astro \\
\hline 1898 & O Republicano \\
\hline 1899 & O Papagaio \\
\hline 1900 & A Seara \\
\hline 1902 & O Municipal \\
\hline 1903 & O Comércio \\
\hline 1904 & O Incentivo \\
\hline 1904 & O Til \\
\hline 1908 & O Viajante \\
\hline 1912 & O Municipio \\
\hline 1913 & O Jornal de Lavras \\
\hline 1914 & O Operário \\
\hline 1914 & O Diário de Lavras \\
\hline 1917 & O Guarany \\
\hline 1918 & O Lavras Jornal \\
\hline 1920 & A Semana \\
\hline 1921 & A Tribuna do Povo \\
\hline 1930 & A Gazeta \\
\hline 1931 & A República \\
\hline 1967 & Tribuna de Lavras \\
\hline
\end{tabular}

Fonte: VILELA, 2007, p. 422-444.

Entre esses jornais das últimas décadas do século XIX, apenas três foram encontrados no arquivo do Museu Bi Moreira da Universidade Federal de Lavras: três edições do jornal $O$ Caracter (n. 53, 91 e 92, de 1895); dezenove edições do jornal O Republicano, entre 1889 e 1901; vinte edições do jornal Folha de Lavras, entre 1898 e 1903. Para uma compreensão de como nessa época eles noticiavam os assuntos urbanos e educacionais, utilizaram-se aqui esses três jornais, com o intuito de perceber não só como estava a cidade de Lavras-MG no final do século XIX, mas também o sistema educacional, tentando uma aproximação entre ambos para caracterizar as categorias de progresso e moderno relacionadas com as questões de urbanização e escolarização.

No jornal Folha de Lavras de $1899^{4}$, são encontrados dados expressivos e questionadores sobre a situação social, econômica e educacional do município de Lavras. No seu sexto ano de existência, após dez anos da Proclamação da República, o redator traz dados de como um governo despótico não estava fundamentado nas leis constituintes do país e cita o Estado de Minas Gerais que, a seu ver, possuía uma Constituição fundamentada nos direitos liberais:

[...] Os governos livres são pois favoráveis aos progressos da rasão humana. Esclarecer o povo não é para elles sómente o cumprimento d'um dever, é uma condição necessaria de sua existencia: A sua segurança está na luz, como a dos governos despoticos está nas trevas. Para julgar pois das intenções secretas d'um governo, basta lançar os olhos sobre as escolas públicas. Todo governo que quizer retrogradar para o poder absoluto, chamará a ignorancia em soccorro da sua conspiração. Como, pois, o Congresso Mineiro tenta por uma reforma iniqua, impatriotica, arrancar o livro das mãos dessas criancinhas e atirá-las desapiedadamente

\footnotetext{
${ }^{4}$ Os primeiros periódicos em Minas Gerais foram publicados na cidade de Ouro Preto, sendo o Abelha de Itacolomi e o Compilador Mineiro, em 1824, e o Universal, em 1825 (JORNAIS mineiros. Disponível em: <http://www.siaapm.cultura.mg.gov.br>. Acesso em: 18 jul. 2013.).
} 
nas trevas do obscurantismo? Como anniquilar o progresso desses pequenos centros que tambem contribuem com o seu obulo para o erario estadual? (FOLHA DE LAVRAS, 17 set. 1899, p. 2, grifos nossos).

Ao se analisar a palavra "progresso" presente nesse escrito, percebem-se dois sentidos: o primeiro está voltado para o progresso da razão, da esperança de que a realidade se transforme por meio da ciência e do conhecimento; ele acena também para a democracia, regime difundido como o melhor para a instalação de um Brasil mais moderno, ao contrário da monarquia, na maioria das vezes tirana, sem a participação popular, que usou durante muitos anos o trabalho escravo e que não garantiu o desenvolvimento do Brasil, alicerçado na igualdade e na liberdade; o segundo está associado à questão material e ao progresso dos pequenos e pobres centros urbanos mineiros, que, mesmo pagando os impostos devidos, não recebiam o retorno das autoridades políticas, como uma educação de qualidade para as crianças.

Por outro lado, pode-se também perceber a influência positivista, que marcou a Proclamação da República, estampando em sua nova bandeira as palavras "ordem e progresso $^{5}$. Para Rossi (2000, p. 95-96), o progresso se configurou como uma necessidade natural a partir das ideias do darwinismo social, sendo a civilização uma parte importante a ser considerada na natureza, fundamentada numa fé no progresso que, a seu ver, estava fundamentada em três convicções:

1. na história está presente uma lei que tende, através de graus ou etapas, à perfeição e à felicidade do gênero humano; 2. Tal processo de aperfeiçoamento é geralmente identificado com o desenvolvimento e com o crescimento do saber científico e da técnica; 3. Ciência e técnica são a principal fonte do progresso político e moral, constituindo a confirmação de tal progresso.

Associando ciência, técnica e progresso, o editorial do jornal $O$ Caracter traz, em sua edição de n. 53 - em que estava completando um ano de existência -, uma alusão bastante expressiva a essa data:

A nossa folha perfaz hoje o seu primeiro anno de existencia. Nesse decurso de tempo julgamos ter feito o possivel por dar regularmente uma gazeta, em cujas columnas havemos propugnado com esforço o progresso desta terra, sem nunca termos desviado das normas de nosso programma. É facil comprehender-se com quantas difficuldades lucta em sua carreira uma folha publicada em nosso pequeno meio social, onde infelizmente ainda faltam certos recursos para a prosperidade de um periodico. Apezar disso, não nos ha faltado alento para proseguirmos nossa rota: o favor popular muito tem bafejado este semanario, e os nossos illustres collaboradores mostraram-se em extremo generosos para com $\mathrm{O}$ Caracter, procurando eleval-o á altura digna de um orgam de publicidade (O CARACTER, p. 1, 27 jan. 1895, grifos nossos).

\footnotetext{
${ }^{5}$ Raimundo Teixeira Mendes nasceu em Caxias, no estado do Maranhão, em 1855. Quando residia na cidade do Rio de Janeiro, influenciado por seu cunhado que havia retornado de Paris e se convertido à religião comtiana, tornou--se um apóstolo e político positivista. Ambos ajudaram Benjamin Constant, um dos líderes políticos responsáveis pela proclamação da República, na confecção da bandeira republicana, colocando no centro do círculo os dizeres "ordem e progresso" com base na frase do fundador do positivismo, Augusto Comte, que associou o amor como princípio, a ordem como fundamento e o progresso como base social (Disponível em: <http://www.dec.ufcg.edu.br/biografias/RaimTeMe.html>. Acesso em: 15 jul. 2013.).
} 
Referindo-se à cidade, o jornal traz em suas edições alguns relatórios municipais apresentados pelo agente do Executivo Municipal à Câmara, enaltecendo o regime republicano por ter garantido mais autonomia aos municípios do que no período da monarquia e, claro, propiciando, assim, a prosperidade das cidades. Essa prosperidade está associada aos subtítulos que ele coloca em seu texto, tais como o cemitério, a iluminação, o trato da água potável e uma notícia que chama muito a atenção: a de uma verba que veio para a compra de "mobília" para as escolas. Ele específica que ela veio "dos Estados-Unidos do Norte", indicando uma possível influência dos missionários americanos residentes em Lavras. Por meio desse relatório, percebe-se, também, como a escola era, em sua perspectiva, uma instituição social importante e, portanto, como as demais, também merecia investimento.

Após doze anos da reforma educacional no Estado de São Paulo, a imprensa lavrense se ocupou, também, de notícias e análises do sistema educacional, noticiando e realçando o progresso das escolas paulistas ${ }^{6}$ e cariocas, ${ }^{7}$ sendo importante aqui destacar pequenos trechos de algumas reportagens que trazem categorias centrais para a análise desta pesquisa:

Si em que ainda não adoptados os systemas modernos de educação que em São Paulo, como se vê do relatorio do sr. Estevam de Oliveira, têm feito progressos admiraveis, as nossas creanças guiadas por um professorado consciencioso vão desenvolvendo aptidões que demandam ensino mais intuitivo, mais pratico, de conformidade com os processos alli seguidos. (FOLHA DE LAVRAS, p. 1, 30 nov. 1902, grifos nossos)

Rossi (2000) diz que a ideia moderna de progresso, além de ter sido fundamentada por teóricos como Condorcet, Turgot, Saint-Simon e Comte, também se afirmou a partir de 1850, quando duas palavras expressavam categoricamente esse cenário progressista: crescimento e desenvolvimento, sendo comuns os discursos voltados para a passagem de um estágio de barbárie para um momento de civilização.

A citação a seguir ilustra essa visão teleológica de progresso presente no século XVIII, cuja finalidade era extinguir o analfabetismo, culpado de todo o atraso econômico e social:

O importantissimo relatorio recentemente publicado pelo illustrado professor Estevam de Oliveira, ao qual já tivemos occasião de alludir, mostra claramente o caminho a seguir, para que tenhamos em Minas o progresso que se nota nas escolas paulistas e fluminenses.

Ainda bem que esse trabalho constitue o primeiro passo dado para a reforma projectada, pois que o governo quando o mandou fazer já estava compenetrado da necessidade urgente de encarar com firmeza o problema do ensino publico, sem o qual o progresso do Estado será uma utopia.

A propria evolução que se nota no ensino, manifestando a boa vontade do professorado, que ainda mesmo sem os meios necessarios de acção, vai já merecendo os encomios da imprensa, está indicando ao governo que é tempo de agir para que se mudem as nossas condições sociaes, e desappareça essa enorme cifra de analphabetos que são o empecilho do nosso progresso. (FOLHA DE LAVRAS, p. 1, 7 dez. 1902, grifos nossos).

\footnotetext{
${ }^{6}$ Uma notícia datada de $1 .^{\circ}$ de junho de 1902 traz informações importantes sobre a visita de Estevam de Oliveira às escolas da cidade de São Paulo, consideradas como as "mais adiantadas do Paiz". Baseando-se nessa visita é que foram traçadas as reformas educacionais acontecidas no Estado de Minas Gerais a partir de 1906, no governo de João Pinheiro (cf. FOLHA DE LAVRAS, p. 1, 1. jun. 1902).

${ }^{7} \mathrm{O}$ modelo educacional de Grupos Escolares paulista foi implantado no Rio de Janeiro em 1896 (cf. PEREIRA, 2005, p. 32).
} 
Nesse trecho, a palavra "evolução" remete-nos aos conceitos darwinistas que se aproximam muito da teoria de progresso, conforme analisada por Rossi. Essa junção foi feita principalmente pelos darwinistas italianos e foi também matéria de explicação de Binetti (1995), que também analisa que no século XX houve uma crise do conceito de progresso. Segundo o autor, o progresso passa a não estar associado nem às teorias evolucionistas de Darwin, tampouco ao mecanicismo, o que produz uma visão de progresso ou retrocesso. Binetti (1995, p. 1.010) refere-se, também, à fé no progresso; mas, diferentemente de Rossi, traz um significado para o termo explicando que somente a noção de um fluxo contínuo para o Universo não é suficiente para caracterizar o progresso, sendo necessária "uma finalidade, um objetivo último do movimento".

Ideias iluministas associadas ao positivismo presentes nos noticiários lavrenses apresentam, também, certo teleologismo, quando o progresso está associado à questão do conhecimento, da formação escolar da população:

Dentre os diversos problemas de que, abordados com boa vontade e resolvidos, adviria o bem-estar e o progresso para o nosso rico municipio, um devia merecer especial attenção dos lavrenses, pois delle se derivaria a estrada larga para a solução de todos os outros que lhe não são mais que simples corollarios. Referimo-nos á instrucção superior da mocidade.

[...].

Lavras tem elementos de progresso e precisa progredir.

(FOLHA DE LAVRAS, p. 1, 14 set. 1903, grifos nossos)

Há várias reportagens como essas que serviriam para demonstrar como o autor faz uso das palavras mudança, avanço, progresso, evolução, reforma e desenvolvimento para ilustrar como a sociedade mineira relaciona o progresso à questão educacional. Mas as que foram demonstradas já são suficientes como indicativos de que educação e progresso se encontravam intrinsecamente ligados e dependentes, sendo o expressivo número de analfabetos um fator determinante do atraso em que se encontrava não somente o Estado de Minas Gerais, mas o país inteiro.

\section{A ordem e o progresso do espaço urbano}

As propostas republicanas para a questão urbana também tomam um rumo progressista e modernizante a partir da Proclamação da República. O processo civilizador (ELIAS, 1939) ${ }^{8}$ dos republicanos inicia-se pelo urbano, com um novo projeto arquitetônico para as cidades, principalmente para as capitais estaduais. $\mathrm{O}$ alargamento das avenidas e a construção de prédios nos moldes europeus imprime um progresso que acena para uma modernidade que se quer alcançar.

Em Lavras, a questão urbana e espacial desponta bem anteriormente a essas ideias de modernidade aplicadas pelos republicanos em algumas capitais brasileiras. Firmino da Costa Pereira ${ }^{9}$, o primeiro diretor do Grupo Escolar de $\operatorname{Lavras}^{10}$, utilizou uma notícia publicada no

\footnotetext{
${ }^{8}$ Apropriou-se somente das palavras de Norbert Elias, mas não de seu conceito e das implicações referentes.

${ }^{9}$ Ele nasceu, circunstancialmente, em Niterói, Rio de Janeiro, em 1869, onde sua mãe se encontrava para um tratamento de saúde. Firmino já era conhecido pelas funções públicas que exercera diante do município lavrense, como secretário da Câmara Municipal, vereador, associado do "Club Literário e Musical" e membro do Congresso Agrícola Industrial e Comercial do Estado de Minas Gerais. Desde sua juventude, trabalhara no comércio do pai, que era proprietário de uma loja. Além de vender produtos diversos, tinha uma oficina de
} 
jornal Imprensa Industrial para ilustrar as transformações ocorridas na cidade ao longo dos anos. $\mathrm{O}$ diretor destaca as transformações sofridas pela praça principal da cidade, como arborização, alargamento e cimentação dos passeios. O ocorrido, registrado na imprensa em 1877, parece não ter uma data certa de quando aconteceu; mas, pelo fato de a comarca de São João del-Rei intrometer-se no caso, tudo indica que foi quando Lavras ainda era uma vila. $\mathrm{O}$ problema surgiu quando alguns moradores desrespeitaram o espaço destinado à praça e começaram a construir casas sem nenhuma licença, o que provocou uma divisão entre as autoridades locais, ao decidir se permitiriam ou não as construções. Dois capitães sãojoanenses anunciaram que destruiriam as casas iniciadas. Diante da incerteza da decisão, dois cidadãos lavrenses, usando força, com a presença de capangas, destruíram as construções e colocaram os homens para vigiar a praça. A população, amedrontada, não se manifestou mais sobre o assunto, e assim o espaço público destinado à praça foi preservado ${ }^{11}$.

Nos estudos históricos sobre as cidades e o urbanismo, as noções sobre "regularidade" e "irregularidade" são desenvolvidas para compreender como uma cidade pode ser organizada de maneira espontânea ou planejada ${ }^{12}$. Bastos $(2007$, p. 30) traz dados sobre o uso da geometria retilínea:

Antes de tratar objetivamente das povoações mineiras, cumpre posicionar a questão da "regularidade" no âmbito dos estudos das povoações coloniais luso-brasileiras. De um modo geral, a noção de "regularidade" que predomina nesses estudos se caracteriza pela geometria uniforme no traçado retilíneo de arruamentos e praças; geometria esta que representaria uma proposição racional do homem, resultante da necessidade de se alcançar uma espécie de 'ordem' prefigurada pelo número, pela constância, pela repetição e pela previsibilidade. Encaixam-se nesta definição não apenas os traçados urbanos dispostos em arruamentos perpendiculares entre si, gerando quadras retangulares ou propriamente quadradas, mas também as cidades, cidadelas e fortificações originadas a partir de 'polígonos regulares', ou seja, cujas faces e ângulos são iguais, com traçados perimétricos e radiais.

marcenaria e um seleiro. Realizara seus estudos preparatórios em São Paulo, mas não chegou a fazer nenhum curso superior (PEREIRA, 2005, p. 36).

${ }^{10} \mathrm{O}$ Grupo Escolar de Lavras foi objeto de estudo da dissertação de mestrado defendida pelo autor desse artigo, na Faculdade de Educação (FaE) da Universidade Federal de Minas Gerais (UFMG), que também trouxe dados importantes sobre a atuação de Firmino da Costa Pereira e suas ideias pedagógicas, apresentando sua carreira como um importante intelectual da educação mineira com várias obras escritas. A partir desse trabalho, muitas outras pesquisas contemplaram ora a atuação de Firmino, ora as ideias pedagógicas contidas no Vida Escolar (cf. PEREIRA, 2006).

${ }^{11}$ Alessandra Teixeira da Silva (formada em Engenharia Florestal pela UFLA) e Patrícia Duarte de Oliveira Paiva (formada em Agronomia e professora de floricultura e paisagismo na UFLA) trazem uma contextualização histórica da praça principal da cidade, demonstrando o zelo que os lavrenses tiveram por ela durante anos, mas principalmente revelando um espaço que muitas vezes serviu para várias representações do corpo, ora para lazer, ora como espaço reservado e cercado onde as pessoas deveriam seguir regras e normas de condutas (cf. SILVA; PAIVA, 2008). Todas essas representações vão sendo construídas ao longo das primeiras décadas do século XX, revelando que as práticas de civilização que devem ser seguidas nos espaços devem ser pautadas por práticas e estratégias, sejam de preservação, sejam disciplinatórias, como escreveu Foucault (2013).

${ }^{12}$ Regularidade e ordem são as categorias principais do trabalho de Bastos (2007), que procura compreender a organização arquitetônica quando o Estado de Minas Gerais ainda era uma Capitania. Ao trabalhar esses dois conceitos, o autor utiliza o trabalho de estudiosos na área da arquitetura, da história, da geografia e da sociologia (cf. BASTOS, p. 30, 2007). 
Esse traço retilíneo era próprio da muitos arraiais, vilas e cidades nessa época. Vilela (2007 p. 41) $)^{13}$ cita que na cidade de Lavras havia uma "Rua Direita", que era "uma rua que conduzia do início ao fim do arraial, tornando-se em seguida, estrada novamente", sendo que, no decorrer de seu desenvolvimento, ela foi ponto para abrigar "diligências, tropas, viandantes, etc.", onde também a permanência de moradores e daqueles que trabalhavam na terra contribuía para "a existência de estalagens, ranchos e roças, respectivamente, mantendo canoas para a travessia do Rio Grande e ainda experimentou a exploração aurífera [...]”.

A fotografia a seguir apresenta esse traçado retilíneo em que a cidade de Lavras fora construída, ilustrando, assim, como essa organização espacial foi construída a partir da demarcação da praça central.

Figura 1 - Cidade de Lavras com destaque para a praça principal.

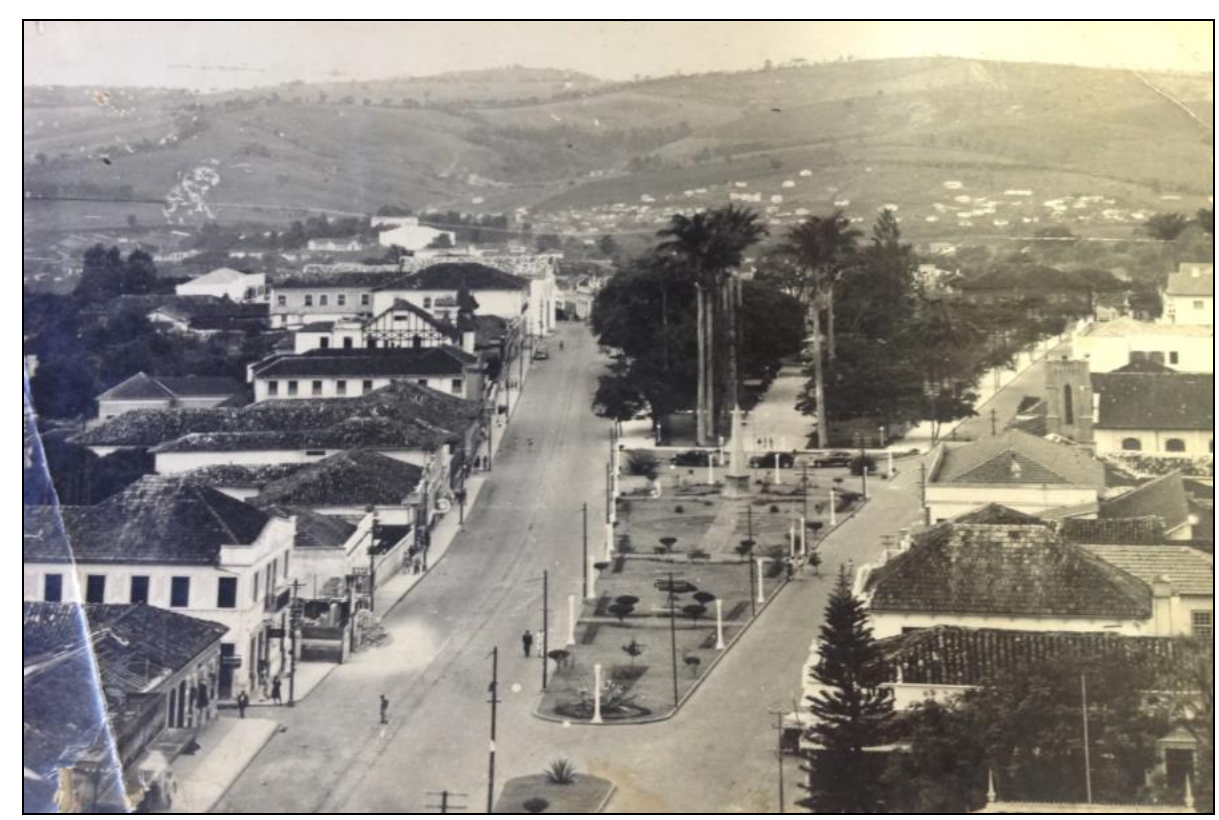

Fonte: Museu Bi Moreira de Lavras. Sem data e sem autoria. Foto tirada da torre da Igreja Matriz de Sant'Ana na cidade de Lavras-MG.

Outras práticas foram contribuindo para a organização da vida na cidade, tais como a numeração das casas iniciadas a partir de 1862 e as categorias de divisão espacial, conforme suas funções: praças, ruas e travessas. Em 1905, foram colocadas placas nas ruas e travessas, com seus respectivos nomes, como também se iniciou o calçamento a partir de 1836 e, na praça principal, o plantio de árvores, em 1853. Nesse mesmo ano, iniciou-se, também, a iluminação da cidade, feita a querosene.

Os relatos de Firmino Costa (VIDA ESCOLAR, p. 4, 1. ${ }^{\circ}$ set. 1907, grifos nossos) sobre a Praça Municipal trazem categorias importantes para a compreensão civilizatória espacial aos moldes republicanos, presentes em palavras tais como avenida, prédios, centro, largo:

A Praça Municipal, tambem conhecida por Largo da Matriz ou simplesmente Largo, fica no centro da cidade e é o ponto principal de Lavras. Arborizada de casuarinas desde 1855, ella é hoje contornada por uma aléa de magnolias e tem uma avenida central de palmeiras, estas duas ultimas plantações feitas em outubro de 1905, por iniciativa

${ }^{13}$ Márcio Salviano Vilela é natural da cidade de Ribeirão Vermelho-MG, cidade próxima à cidade de LavrasMG. Ele é formado em Agronomia pela Universidade Federal de Lavras (UFLA) e exerceu por conta própria pesquisas sobre a cidade de Lavras, publicadas em um livro de sua autoria (cf. VILELA, 2007). 
do nosso conterraneo sr. Gustavo Penna. A Praça Municipal está passando presentemente por notavel transformação, devida em grande parte ao actual presidente da Camara sr. Pedro Salles, cujos esforços vão sendo imitados pelos proprietarios. Em breve estará toda a Praça ajardinada, assim como dotada de passeios largos e cimentados. Ella conta 34 predios, entre os quaes a casa da Camara, a igreja matriz e o templo evangelico; bastante espaçosa, ella se extende de certo ponto do jardim Barão de Lavras até a travessa do Rosario, indo-se estreitando em sua parte superior, cuja largura é de 32 metros, ao passo que a da parte inferior é de 90 metros, sendo de 340 metros o comprimento da Praça.

Todo esse espaço quase ficou comprometido com sua invasão no século passado, se algumas pessoas da comunidade não tivessem percebido a necessidade de preservação desse local, como o centro comercial, religioso e até social, pois é a praça é o espaço onde se realiza o lazer, onde as gerações se encontram, local de realização das mais variadas manifestações e de aglomerações dos principais prédios, como das igrejas, dos hotéis e do comércio em geral.

Se a ordem espacial estava sob controle, já a situação social muitas vezes era preocupante, e a única esperança para a melhoria das condições sociais era a escola.

Outra situação é relatada num artigo de 1899, publicado no jornal Folha de Lavras (p. 1, 19 mar. 1899, grifo nosso), destacando o papel importante das Câmaras Municipais, que, por meio de seus vereadores, vinham criando escolas primárias e secundárias, o que, no parecer do escritor, significava uma parte importante da garantia do progresso:

$\mathrm{Si}$ o nosso municipio que conta extraordinarios elementos de progresso, na uberdade de seu solo, nas extensas campinas que podem compor ter ${ }^{14}$ creação de animaes de todas especies, não tem sido o desenvolvimento que era pra desejar-se, deve-se levar em conta deste atraso relativo a falta de instrucção no povo. E este mesmo conceito que externamos se estende à maioria dos municipios mineiros, que antes definhavam e morriam a mingua de instrucção que collocasse o povo na altura da comprehensão de seus deveres sociais.

A garantia do desenvolvimento urbano, na perspectiva dessa citação, está intrinsecamente associada à formação acadêmica dos moradores da cidade. Será por meio dela que os males sociais praticados por jovens analfabetos vão ser extintos, como a bebedeira, os jogos de carta e a vadiagem. Para esses foi desenvolvida no município a educação secundária, uma aula noturna de alfabetização de adultos e houve o aumento, também, de duas cadeiras de educação primária em regiões mais afastadas, que constituíram "mais dois elementos de progresso para o nosso município", no parecer do autor do artigo (FOLHA DE LAVRAS, p. 1, 19 mar. 1899).

O desenvolvimento e o progresso também são colocados pelo autor do artigo em diferentes perspectivas, pois os fundamentos necessários para o progresso existem, mas os elementos para o desenvolvimento estão sendo criados, por isso mesmo são lançados num futuro incerto.

\footnotetext{
${ }^{14}$ Não foi possível decifrar qual é essa palavra, dada a precariedade das condições materiais da parte desse jornal.
} 
Acompanhar o desenvolvimento da cidade de Lavras implica estar atento à forma como ele é apresentado e representado. O primeiro cidadão lavrense a se ocupar de tal empreendimento numa perspectiva histórica é Firmino Costa, que utiliza um instrumento de divulgação inédito, um boletim escolar quinzenal, criado por ele mesmo e intitulado Vida Escolar ${ }^{15}$.

Para escrever sobre a história da cidade, Firmino pesquisava em documentos encontrados na Câmara Municipal e nos arquivos da Igreja, como também recorria a depoimentos orais. Após a coletânea desses dados, ele os publicava num jornal local e, como diretor do Grupo Escolar, começou a transcrever esses dados coletados para o periódico Vida Escolar. (VIDA ESCOLAR, p. 4, 1. ${ }^{\circ}$ abr. 1908)

Compreender os motivos que fazem esse diretor inserir dados sobre a história de uma cidade num boletim escolar que deveria trazer somente dados escolares é entender que sua visão de espaço escolar estava muito além do que se imaginava na época, vendo a escola como a guardiã das tradições culturais, dos costumes e das informações acerca da vida não somente do local onde ela estava inserida, como também das pessoas que na cidade residiam.

Essa visão do diretor é como se fosse a extensão do que era a sua vida, entrelaçada em funções públicas, ora como escritor, ora como vereador, ora como professor, pai de família, membro de partido político e clubes literários. Sua atuação acontece em determinado espaço territorial, e sua vida se insere na própria missão que ele tantas vezes trilhou, buscando o progresso, o desenvolvimento, fundamentado num projeto de civilização que englobava tanto o setor político ${ }^{16}$ quanto o econômico, o religioso, o educacional e, principalmente, o social.

Mas não cabe aqui analisar a pessoa e as obras desse intelectual mineiro, e sim acompanhar partes de seu raciocínio acerca de progresso e desenvolvimento inserido em seus apontamentos sobre a história da cidade.

Na primeira edição do boletim Vida Escolar, o diretor do Grupo apresenta dados sobre a história de Lavras, trazendo informações de quando as terras foram doadas, por meio de uma carta de sesmaria, em 1737, aos bandeirantes Pedro da Silva de Miranda, Francisco Bueno da Fonseca, Salvador Jorge Bueno, Paschoal Leite Paes, Diogo Bueno e Manuel Francisco Xavier Bueno. Para Vilela (2007, p. 16), a partir desse momento, “[...] Lavras passa a povoar-se, dando livre curso às suas tendências socioeconômicas e culturais, associadas às novas famílias que organizaram domicílios [...] determinando, assim, a condição elevada de vida [...]". Destaque-se aqui que, nesse primeiro momento, ele escolhe a palavra povoamento e não utiliza a palavra progresso ou desenvolvimento nem nessa parte, como também quando se refere às famílias, o que não é usual quando se refere às condições sociais e econômicas.

\footnotetext{
${ }^{15}$ Criado com o objetivo de informar a cidade e mesmo o Estado sobre a instrução acontecida em Lavras, o Vida Escolar traz dados estatísticos sobre o progresso e o desenvolvimento do Grupo. O boletim circulou de maio de 1907 a novembro de 1908, com 34 números editados quinzenalmente, menos nos períodos de férias. Sua impressão era feita na gráfica do jornal Folha de Lavras, de propriedade do filho do professor Azarias Ribeiro, diretor da Escola Normal. Constava de quatro páginas com as seguintes seções fixas, referentes a acontecimentos, locais ou não, de interesse do ensino: notícias, comemorações; história de Lavras, grupo escolar, corografia de Lavras. Além disso, publicava comentários pedagógicos, quase sempre de autoria de Firmino Costa e alguns assinados por outros professores (cf. PEREIRA, 2005, p. 58). Sobre o boletim, confira a seguinte obra: GALVÃO, Ana Maria de Oliveira; LOPES, Eliane Marta Teixeira. (Orgs). Boletim Vida Escolar. Uma fonte e múltiplas leituras sobre a educação no início do século XX. Belo Horizonte: Autêntica, 2011.

${ }^{16}$ Muitas de suas reformas educacionais aplicadas no Grupo Escolar de Lavras se tornaram modelo para os outros grupos escolares do Estado, como também várias de suas sugestões foram acolhidas pelos governadores estaduais.
} 
A fundação da cidade de Lavras deveu-se à vinculação da doação de sesmarias no entrecruzamento de bandeiras, povoamento e exploração aurífera. Passada essa fase, a agropecuária e a construção da Capela de Sant'Ana ${ }^{17}$ foram a garantia de "um novo ritmo à vida econômica do arraial, gerando modificações importantes nos aspectos sociais, administrativos e políticos" (VILELA, 2007, p. 51). Portanto, em nenhum momento, a escola foi apresentada como uma instituição importante na constituição primitiva da cidade de Lavras e no seu desenvolvimento e progresso.

Um olhar muito expressivo sobre a situação urbana de Lavras se encontra num relato escrito pela segunda esposa de Samuel Gammon, o qual esteve à frente do Instituto Presbiteriano durante muitos anos:

Lavras era, naquele tempo, uma velha cidade, datando dos dias coloniais, e, como o seu nome indica, tinha sido cenário de grande mineração, na busca do ouro que enriquecia a coroa de Portugal. Podese dizer que só havia uma rua, que se estendia em ziguezague pela colina, cêrca de quatro quilômetros [...]. As ruas eram poeirentas ou lamacentas, conforme a estação, e ainda rasgadas pelas rodas dos pesados carros de boi. As casas, em geral, eram de construção simples, mas sempre pintadas de cores variegadas. Na praça central, grande e deserta, onde se erguia a Igreja Matriz, havia um certo número de sobrados, onde vivia a elite. Estas casas, de estilo colonial, eram bem mobiliadas e adornadas com pinturas e revestimento caprichoso, refletindo o luxo e a riqueza de dias prósperos. Nos arredores da cidade, porém, se amontoavam os casebres cobertos de capim, atestando a maior pobreza. Eram assim as cidades antigas do interior de Minas. Hoje o progresso já invadiu aquelas regions montanhosas. As ruas foram endireitadas, pavimentadas e dotadas de passeios. As praças se transformaram em parques e jardins. As casas são de estilo moderno e de aparência imponente. As habitações dos pobres vão sendo melhoradas à custa de associações particulares e dotações do govêrno. Os carros de bois foram afastados do perímetro da cidade e não se permite que os animais vagueiem pelas ruas (GAMMON, 1959, p. 6465 , grifos nossos).

Esse relato foi escrito em um livro editado em 1959, quando a missionária retrata como era a cidade assim que as primeiras missionárias começaram os seus trabalhos em Lavras, em $1893^{18}$. Vê-se um tempo caracterizado por miséria e falta de organização, mas com indícios de prosperidade, principalmente presente na "elite" que também residia na Vila. E os "dias prósperos" são confirmados pela autora com a existência de parques, jardins e

\footnotetext{
${ }^{17}$ Há uma forte influência da Igreja Católica nas formações urbanas em Minas Gerais no século XVIII, quando os próprios lavradores e mineradores construíam suas casas ao redor de uma capela, símbolo da devoção popular. A história do povoado de Lavras está inserida nesse contexto, quando Romualdo Golungo, da bandeira de Bartolomeu Bueno da Silva, conhecido como o Anhanguera, passando pela Colina do Funil nos anos de 1698, em busca de ouro e prata, desaparece entre as águas do rio e somente volta após três dias, fato que foi tido como um milagre de Sant'Ana, o que culminou posteriormente na construção de uma capela à santa, que também era padroeira da bandeira de Bartolomeu Bueno da Fonseca (cf. VILELA, 2007, p. 41, 201).

${ }^{18} \mathrm{Em}$ outra parte do livro sobre a vida de Samuel R. Gammon, a autora fez outra referência às ruas da cidade semelhante a citação apresentada, mas com data de 1895, portanto dois anos depois: “[...] As ruas da cidade não eram calçadas, de sorte que se tornavam quase intransitáveis de setembro a março. Para isto concorria os carros de bois, com suas rodas fortemente ferradas que abriam grandes sulcos nas vias públicas, como nas estradas (GAMMON, 1959, p. 81).
} 
casas modernas, o que demonstra como, para a passagem de um século ao outro, o desenvolvimento é explícito. Em seu parecer, ela teve o acompanhamento e a contribuição de seu marido, Samuel Gammon, que "iria partilhar das alegrias e tristezas do seu povo; iria tornar-se uma parte da própria vida dela" (GAMMON, 1959, p. 65). Usando a frase "do seu povo", Clara Gammon denota o sentido de que o missionário estrangeiro já se considerava um brasileiro, o que justifica sua dedicação, até a morte, ao Instituto Presbiteriano em Lavras.

O quadro a seguir apresenta dados anteriores a 1893 de como também as escolas surgiram por meio de iniciativas particulares e voluntárias, principalmente por pessoas vinculadas à religião católica, significando que ainda não havia nenhuma preocupação das autoridades políticas municipais em criar escolas para a comunidade. Somente em 1874, mais de cem anos depois, é que acontece, por parte do município, a criação de um local para a educação pública. Ainda no final do século XVIII, também há o surgimento de escolas confessionais na cidade, sendo que primeiro ele acontece por parte dos presbiterianos e, depois, no século XX, pelos católicos, não surgindo, portanto, nada de expressivo por parte do poder estatal ou municipal que transformasse a realidade da educação.

Quadro 2 - Escolas existentes na cidade de Lavras-MG do final do século XVIII ao final do século XIX

\begin{tabular}{|c|l|}
\hline Ano & \multicolumn{1}{|c|}{ Escolas } \\
\hline 1792 & Escola Pública Primária de Pe. Manoel Moreira Prudente \\
\hline 1828 & $\begin{array}{l}\text { Escola Pública Secundária de Pe. Francisco d'Assis Braziel (aulas em nível secundário de } \\
\text { Latim, Francês, Geografia, Desenho, Aritmética e Música) }\end{array}$ \\
\hline 1832 & Três escolas particulares de Primeiras Letras (62 alunos) \\
\hline 1833 & Escola Pública de Raymundo Nato Brasileiro (40 alunos) \\
\hline 1851 & Colégio Mineiro de Pe. Flávio Ribeiro de Almeida \\
\hline 1857 & Escola Pública Primária de D. Guilhermina Cassiana Brasileiro \\
\hline 1874 & Casa de Instrução - Escola Municipal \\
\hline 1882 & $\begin{array}{l}\text { Colégio dirigido pelo Pe. Gustavo Ernesto Coelho (aulas de Francês, Português, Latim, } \\
\text { Matemática, Geografia e Música. }\end{array}$ \\
\hline 1883 & Escola Noturna para alfabetização \\
\hline 1887 & Escola do Professor Daniel Balbino de Noronha Almeida \\
\hline 1887 & Escola Noturna gratuita para os libertos \\
\hline 1893 & Instituto Evangélico \\
\hline 1898 & Escola Noturna Municipal \\
\hline 1898 & Externato Municipal \\
\hline 1899 & Colégio Lavrense - primeiro estabelecimento oficial de ensino secundário \\
\hline 1900 & Colégio N. Sra. de Lourdes \\
\hline
\end{tabular}

Fonte: VILELA, 2007, p. 224.

Nos registros sobre a história de Lavras, a palavra "progresso" foi utilizada por Firmino Costa no seu oitavo apontamento, quando ele toma a data inicial de edificação da cidade em 1737 e a compara com a situação da cidade em 1754, quando possuía 43 casas, e com 245 prédios em 1832, o que para ele significava admitir "que o crescimento de Lavras foi egualmente progressivo" (VIDA ESCOLAR, p. 3, 15 jul. 1907).

Firmino Costa, como professor de Português, escolheu a palavra "Progresso", que condiz com o que ele quis demostrar: o aumento de número de casas ao longo de um período de 95 anos, como também outros progressos e desenvolvimento, como a construção de prédios públicos, dos números de habitantes, de escolas e da vida econômica e social: 
Quadro 3 - Principais prédios existentes na cidade de Lavras de 1754 até a última década do século XIX

\begin{tabular}{|c|l|}
\hline Ano & \multicolumn{1}{|c|}{ Prédios } \\
\hline 1754 & Igreja de N. Sra. do Rosário \\
\hline 1819 & Capela de N. Sra. das Mercês \\
\hline 1848 & Capela de Santo Antônio \\
\hline 1853 & Cemitério \\
\hline 1854 & Casa da Câmara \\
\hline 1862 & Teatro Municipal \\
\hline 1866 & Irmandade de N. Sra. das Dores - Sta. Casa \\
\hline 1873 & Casa de Instrução e Casa do Colégio \\
\hline 1880 & Santa Casa \\
\hline 1884 & Capela de S. Miguel no cemitério \\
\hline 1889 & Templo Evangélico \\
\hline 1895 & Cadeia regional e Estação Ferroviária \\
\hline
\end{tabular}

Fonte: VILELA, 2007, p. 142.

O quadro apresenta dados em ordem cronológica de quando surgiram as principais instituições na cidade de Lavras. Interessante perceber novamente que algumas delas antecedem o surgimento de um lugar específico para as escolas, como o Teatro Municipal, que ainda será analisado.

No parecer de Vilela (2007, p. 57), o povoado de Lavras, naquela época, em 1831, era considerado "um importante núcleo urbano pelo número de habitantes e pela variedade das atividades ali desenvolvidas como a prestação de serviços e o movimento comercial desta zona". Em 1832 havia, na cidade, 245 casas, sendo a Igreja da Matriz, as capelas do Rosário e das Mercês os únicos locais públicos. Não havia calçamento em nenhuma rua, tampouco um cemitério. As pessoas ou eram sepultadas dentro da Igreja Matriz, ou em seu entorno. Após 42 anos, Lavras já possuía 371 casas, um aumento não muito significativo, um cemitério e o Largo da Matriz arborizado como progresso. Em desenvolvimento, quer dizer, em projetos, havia planos para a instalação da Santa Casa, a navegação do Rio Grande, a construção da estrada de ferro ligando a Vila à cidade do Rio de Janeiro e uma cadeia, como também havia a preocupação com a canalização de água potável para os moradores. Tudo isso, no parecer de Vilela $(2007$, p. 71$)$, representava o "desenvolvimento e progresso do município" por meio de realizações e esforços de suas lideranças políticas.

A associação das palavras "desenvolvimento" e "progresso" parecem aqui usadas de maneira indistinta pelo autor do livro; mas percebe-se claramente que, sem intenção, ele faz uma distinção explícita do que está em desenvolvimento para culminar no que ele pretende mostrar como consequência disso tudo, que seria o maior progresso almejado pelos moradores da Vila de Lavras do Funil: a transformação do povoado em cidade.

Analisando os fatos acontecidos desde a fundação do município até 1841, Firmino Costa considera, em seu apontamento de número XXI sobre a História de Lavras, que "nada de extraordinario occorreu em Lavras", citando, além dos fatos realçados no QUADRO 3, a educação na cidade, destacando o cuidado que o poder público sempre teve com a instrução lavrense, utilizando a palavra movimento com o significado de que ela não esteve parada, estática, mas denotando que houve um empenho: "Em seus relatórios, o fiscal do municipio prestava sempre informações sobre o movimento da instrucção em Lavras, e a Camara não perdia ensejo de interessar-se pelo desenvolvimento intellectual da villa" (VIDA ESCOLAR, p. 4, 1. jul. 1908, grifos nossos). As palavras movimento e melhoramentos possuem, em sua perspectiva, o que ele considera como desenvolvimento, mas não como extraordinário. Do ponto de vista de Firmino Costa, o que seria um fato, um acontecimento extraordinário? Em sua perspectiva, seria a realização de "grandes melhoramentos locaes" (p. 4) que não foram realizados por falta de verba, já que a receita da Vila era muito baixa? Mesmo se essas realizações não tivessem sido consideradas fora do comum do ponto de vista de Firmino, percebe-se que houve um avanço na criação e na organização de algumas instituições. Talvez o fato extraordinário esperado tenha sido a transformação da vila em cidade. 
Quadro 4 - Principais eventos e instituições surgidas na cidade de Lavras/MG no século XIX

\begin{tabular}{|l|l|}
\hline Ano & Outras instituições \\
\hline 1831 & Criação da Vila de Lavras do Funil \\
\hline 1832 & Instalação da Câmara Municipal (funcionando em casas particulares) \\
\hline 1834 & Agência do correio \\
\hline 1868 & Transformação da vila em cidade \\
\hline 1885 & Abastecimento de água \\
\hline 1889 & Telégrafo \\
\hline 1893 & Iluminação da cidade a querosene \\
\hline 1895 & Estação Ferroviária de Lavras \\
\hline 1892 & Comissão Geográfica e Geológica do Estado \\
\hline 1894 & Clube Progressista Lavrense \\
\hline 1894 & Centro Espírita \\
\hline 1899 & Templo Evangélico Presbiteriano \\
\hline
\end{tabular}

Fonte: VILELA, 2007, p. 71.

Pelo quadro acima, a passagem de vila para cidade se deu em 1868. Os dados são apresentados por Vilela (2007, p. 71), que mistura informações sobre o surgimento da escola.

Para a compreensão da palavra evolução, parte-se em defesa da hipótese de que o século XIX trará o desenvolvimento de instituições que culminará no progresso urbano, mas não necessariamente poderá ser dito que um século foi mais moderno do que o outro e que essa modernidade foi trazida pelas transformações econômicas ocorridas ao longo do século XX.

Ainda como vila, em 1862, na cidade foi construído um teatro monumental, similar ao do modelo arquitetônico do Scala de Milão ${ }^{19}$. A partir dos meados do século XVIII, o teatro passou a ter características educacionais, culturais e artísticas expressivas tanto em nível internacional quanto nacional, e várias peças eram apresentadas em todo o Brasil. Daí nasceu a necessidade de construir lugares específicos para as apresentações teatrais ${ }^{20}$, surgindo, assim, em vários lugares do país, as conhecidas Casas da Ópera. A mais antiga de todo o Brasil e mesmo da América do Sul é a Casa de Ópera da cidade de Ouro Preto, inaugurada em 1770. Na região de Lavras, a cidade de São João del-Rei abriu o teatro para o público em 1778, como também o fez Sabará, com a Casa da Ópera, que iniciou suas atividades a partir de 1819. Em vários outros lugares, os espetáculos aconteciam em espaços públicos.

O processo civilizatório na cidade de Lavras se deu, primeiramente, por meio de instituições de socialização não escolares, como o teatro. Uma elite modernizante ${ }^{21}$, como comentado, juntou-se para arrecadar fundos e fazer doações para a construção de um teatro nos moldes italianos, e não para a construção de um prédio escolar ${ }^{22}$.

\footnotetext{
${ }^{19}$ O Teatro alla Scala está localizado na cidade de Milão, na Itália. Ele serviu de modelo para a construção do teatro da cidade de Lavras, após o incêndio do teatro Regio Ducale, em 1776. A nova construção foi aberta ao público em 3 de agosto de 1778, e ainda nos dias de hoje continua sendo uma referência de casa de espetáculos em nível internacional (TEATRO alla Scala de Milão: a casa da ópera! Disponível em: <http://www.aloartista.com/conteudo.asp?id=142>. Acesso em: 15 fev. 2018).

${ }^{20}$ Posteriormente, os tipos de construções feitas para abrigar os teatros foram divididos conforme as influências sofridas: os primeiros teatros receberam forte influência barroca italiana presentes em alguns prédios construídos no século XVIII; depois há uma influência do Classicismo francês, como também do italiano, e, no século XX, influência do ecletismo francês (ESTILOS: teatros do Brasil. Disponível em: <http://www.ctac.gov.br/tdb/portugues/introducao.asp>. Acesso em: 4 mar. 2018).

${ }^{21}$ Analisar as intenções dessa elite faz levantar questões sem respostas: Quem seriam essas elites? Teriam elas propósitos voltados para a formação cultural da cidade? Havia sessões voltadas para os públicos infantil e adolescente, ou só era permitida a entrada de jovens e adultos?

${ }^{22}$ Somente a partir de onze anos foi que a Câmara Municipal construiu um lugar específico para funcionar a educação primária, a secundária e a escola de alfabetização de adultos. Antes disso, existiam as escolas isoladas, que funcionavam em casas particulares ou mesmo nos espaços cedidos pela Igreja Católica e, muitas vezes, em estado de precariedade (PEREIRA, 2005, p. 25).
} 
Na segunda metade do século XVIII, Rousseau e alguns filósofos travaram uma discussão sobre a função social que as encenações teriam, acontecidas tanto publicamente quanto nos teatros. O primeiro filósofo a escrever sobre esse assunto foi D'Alembert, publicando, em 1757, na imensa obra Enciclopédia, no verbete "Genebra": "[...] a importância do teatro a fim de aperfeiçoar o gosto e os costumes dos povos e exortava os genebrinos a revogarem as leis que proibiam sua instalação na cidade" (MATOS, 1993, p. 7).

Para Matos (1993, p. 8), escritor da apresentação do livro Carta a D'Alembert, JeanJacques Rousseau, como autor dessas cartas, opõe-se explicitamente aos enciclopedistas, levantando questões sobre a utilidade ou não dos espetáculos: "Rousseau sustenta que o espetáculo teatral não é bom em si mesmo, pois, além de ser incapaz de transformar em bons os maus costumes, pode muito bem provocar o efeito inverso, quer dizer, transformar em maus os bons costumes."

Esses fatos, acontecidos quando a cidade de Lavras ainda estava se desenvolvendo como Vila, levam-nos a perceber que, nas cidades da Europa, pequenas ou grandes, o teatro vai ser símbolo de uma modernidade, instalado conjuntamente com um regime político que se dizia também moderno: o republicano.

Lavras ainda era uma cidade pequena, sob um regime monárquico, como várias outras cidades mineiras, e mesmo assim instituiu espaços consagrados à apresentação dos espetáculos. Esses nunca deixaram de acontecer no Brasil; ao contrário, vieram juntos com os padres jesuítas, que utilizaram da arte das encenações como estratégia de evangelização e conversão dos povos primitivos. Mas cabe aqui destacar a discussão, iniciada por Rousseau em 1758, do papel pedagógico dos teatros como um lugar que pode instruir, mas também fomentar os maus costumes.

Figura 2 - Fachada do Teatro Municipal de Lavras

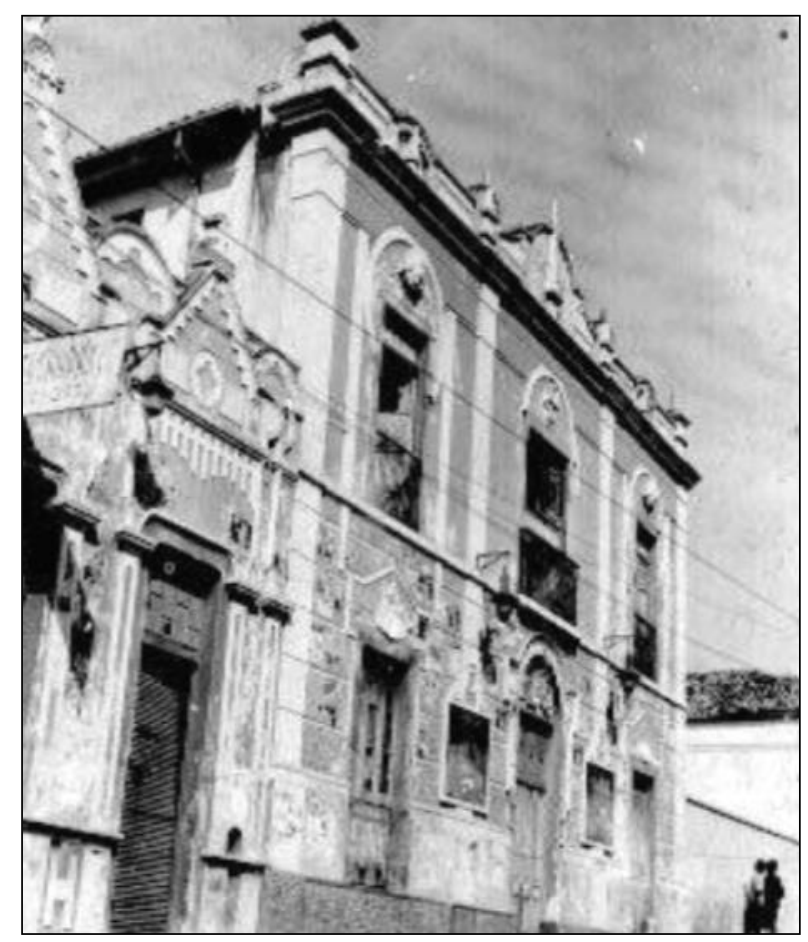

Fonte: Museu Bi Moreira. Sem autoria, sem data. 
Figura 3 - Interior do Teatro Municipal de Lavras

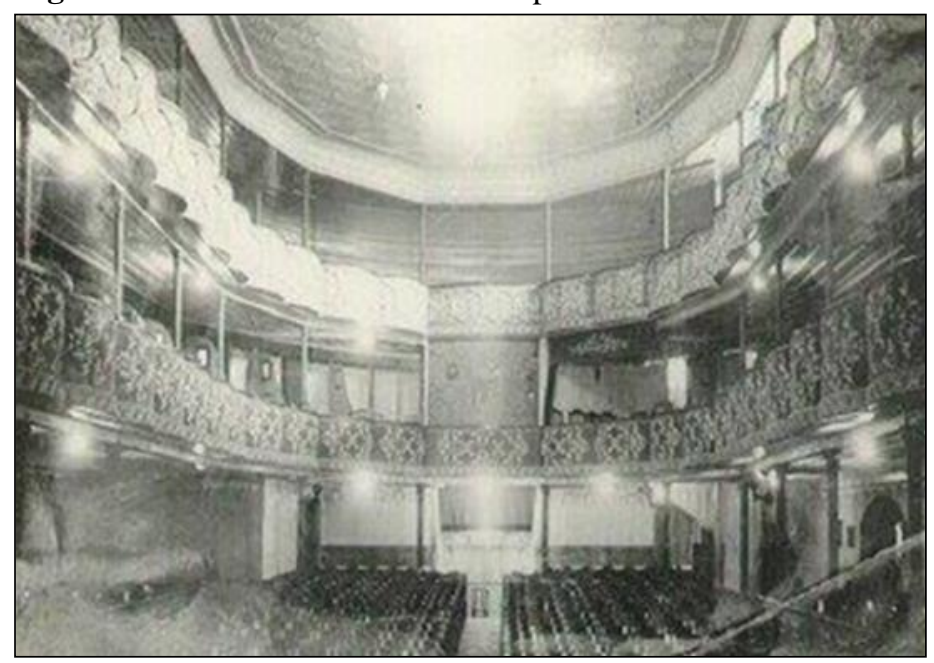

Fonte: Museu Bi Moreira. Sem autoria, sem data.

Qual era a força propulsora na construção dessa instituição na cidade de Lavras? Uma força de um membro da comunidade que, tudo indica, encontrava-se movido por um amor às artes, tomando a liderança e contagiando uma elite modernizante em prol da construção do teatro, arrecadando de cada um uma alta quantia para a época: $100 \$ 000$ (cem mil réis) ${ }^{23}$.

Mas somente a existência dessas modernas construções em estilo europeu não garantia o desenvolvimento da vila; e, por outro lado, a transformação de vila em cidade também não significava a evolução local, pois, para Vilela (2007, p. 71), ainda faltavam muitos melhoramentos materiais para que acontecesse "o desenvolvimento e progresso do município".

Um dos maiores problemas colocados por Vilela era a falta de estradas que permitissem a ligação com outros centros urbanos, principalmente do lado onde passava o Rio Grande, problema que foi solucionado com a construção de uma ponte que se iniciou em 1844 e somente foi concluída após 25 anos.

Outro fator determinante para o encurtamento das distâncias e a ligação com vários municípios e até outros Estados foi a construção de uma malha férrea. Diferentemente dos países da Europa, onde esse transporte surgiu em razão do transporte de minério para a indústria, no Brasil a produção de café impulsionou o desenvolvimento das ferrovias ${ }^{24}$ para transportar esse produto até os portos. Em Lavras, uma estação foi construída em 1888, num lugarejo próximo, escolhido estrategicamente, conhecido como Ribeirão Vermelho, às margens do Rio Grande. Somente após a Proclamação da República é que a cidade de Lavras passou a ter uma estação, quando o presidente da Província de Minas aumentou a malha ferroviária e incentivou o transporte fluvial pelas águas do Rio Grande. A partir de 1892, vários investimentos foram feitos tanto em Lavras quanto na região:

\footnotetext{
${ }^{23}$ Firmino da Costa Pereira foi quem registrou esse acontecimento no seu apontamento n. 8, publicado no boletim do Grupo: "Em 1862, formou-se em Lavras uma associação particular, por meio de acções do valor de cem mil reis, para o fim de levar a efeito a construção do Theatro Municipal, que a princípio se chamou Theatro Sant'Ana. Quem mais activou as obras desse edifício foi o falecido Francisco do Couto e Silva, um dos diretores da associação. Em 1882, diversos acionistas cederam suas partes à municipalidade, que mandou concertar o theatro e tem sabido zelar delle" (VIDA ESCOLAR, p. 4, 15 jul. 1907).

${ }^{24} \mathrm{O}$ famoso Barão de Mauá, Irineu Evangelista de Sousa, foi pioneiro em investir no Brasil tanto no transporte férreo quanto fluvial, criando a Companhia de Navegação e Vapor e Estrada de Ferro de Petrópolis em 1854; portanto, desde seu nascimento, o sistema ferroviário brasileiro cresceu por meio da iniciativa privada, principalmente no período do Segundo Reinado (cf. VILELA, 2007, p. 303).
} 
ocorre a construção da grande 'ponte metálica' sobre o Rio Grande, e, nos anos seguintes, prosseguem a construção das oficinas e rotunda (1895), e prédio da administração da Cia. Agrícola e Industrial Oeste de Minas (1897) [...] em Ribeirão Vermelho (VILELA, 2007, p. 395)

Mas essa construção e outros melhoramentos somente foram possíveis com a instalação da primeira Câmara Municipal, que elegeu vereadores que buscaram "impulsionar materialmente" (VILELA, 2007, p. 395) o município, o que representou a difusão plena do desenvolvimento e do progresso, por meio da "autonomia político-administrativa" (p. 395) que ocorreu com a mudança da vila em cidade.

A inauguração da Casa de Instrução ${ }^{25}$ em 1874 está também entre os bens materiais, como a instalação da Câmara e a construção da ponte, que contribuíram para o desenvolvimento e o progresso da cidade.

Vilela (2007) também faz um levantamento importante para o fechamento da década de 1890, apresentando dados sob várias perspectivas. Esses dados apresentam categorias importantes a serem analisadas, quando o autor se refere à Proclamação da República e às situações econômicas, políticas e sociais que a antecederam.

Economicamente, o município de Lavras, na década de 1890, apresentava intensa cultura alimentícia, que tinha como base a produção da cana-de-açúcar e do fumo, além dos produtos principais de alimentação, tais como o arroz e o feijão, bem como o cultivo do café e do algodão.

No Quadro 5, a seguir, pode-se perceber quando surgem as primeiras fábricas na cidade, com um importante ramo de industrialização: os tecidos.

Quadro 5 - Produtos manufaturados na cidade de Lavras desde sua fundação, no século XVIII, até a primeira década do século XX

\begin{tabular}{|c|l|}
\hline Ano & \multicolumn{1}{|c|}{ Economia } \\
\hline 1737 & Mineração e agropecuária. \\
\hline 1866 & $\begin{array}{l}\text { Toucinho, fumo, bois, queijos, açúcar, porcos, carneiros, algodão, café e gêneros de primeira } \\
\text { necessidade. }\end{array}$ \\
\hline 1880 & $\begin{array}{l}\text { Cana-de-açúcar, fumo, café, algodão, gado bovino e suíno, vinho, licores, cervejas, velas e } \\
\text { frutas. }\end{array}$ \\
\hline 1886 & Companhia de fiação e tecidos União Lavrense. \\
\hline 1890 & $\begin{array}{l}\text { Agropecuária (bovino e suíno), cana-de-açúcar, fumo, algodão, café, rebanho leiteiro e } \\
\text { gêneros de primeira necessidade. }\end{array}$ \\
\hline 1908 & $\begin{array}{l}\text { Café, cereais, fumo, cana-de-açúcar, aguardente, queijo, manteiga, gado, cal, cascas de } \\
\text { barbatimão e tecidos de algodão. }\end{array}$ \\
\hline
\end{tabular}

Fonte: VILELA, 2007, p. 73; VIDA ESCOLAR, p. 4, 1. ${ }^{\circ}$ set. 1908.

Para Firmino Costa, o município não possuía forte setor industrial, apresentando o que existia em Lavras: "Possue a fabrica de tecidos União Lavrense, dezenove fábricas de manteiga, algumas de queijo, diversas caieiras, várias olarias, entre as quaes a ceramica [...]" (VIDA ESCOLAR, p. 4, 1. ${ }^{\circ}$ set. 1908). Nesse parágrafo, o autor faz uso das palavras indústria e fábrica numa mesma sentença, ora referindo-se à "indústria pastoril", que, a seu ver, estava progredindo, ora para indicar que a cidade não tinha uma "grande atividade industrial" (VIDA ESCOLAR, p. 4, 1. ${ }^{\circ}$ set. 1908).

${ }^{25}$ A Associação Propagadora da Instrução e a Associação Propagadora da Instrução Pública foram iniciativas particulares tomadas em alguns municípios mineiros, que procuraram, com recursos próprios, manter a instrução pública, principalmente para os adultos analfabetos, com cursos noturnos. Em Lavras houve a construção de um lugar específico, conhecido como a Casa de Instrução, onde funcionava o ensino primário; no mesmo terreno, havia também a Casa do Colégio, provavelmente para funcionamento da educação secundária pública (cf. PEREIRA, 2005, p. 25-26). 
Hees (2011, p. 101) reflete que há dificuldade em entender as ideias acerca das indústrias no Brasil no século XIX, pois o termo sempre foi utilizado pelas elites brasileiras, mesmo quando o Brasil ainda era colônia. Portanto, em seu parecer, faz-se necessário entender o verdadeiro sentido desse termo, principalmente na imprecisão como ele é colocado, como foi citado por Firmino Costa, pois pode-se correr o risco de um anacronismo ou de se fazerem atribuições de conceitos errôneos de determinada época histórica. O autor cita, então, Adam Smith, “em sua clássica obra A riqueza das Nações, publicada em 1776, em plena Revolução Industrial", tomando palavras presentes em sua obra, tais como "indústrias caseiras" e "industrializar", o que para Hees significou que Smith passa a impressão de que a palavra "industrializar" seria equivalente a "manufaturar", isto é, agregar algum valor ao resultado da atividade agrário-pastoril" (SMITH, 1985, p. 43 apud HEES, 2011, p. 101).

Hees (2011, p. 102), novamente, apresenta uma feliz interpretação para essa confusão de vocábulo, quando analisa alguns escritos do senador Holanda Cavalcanti e percebe que a expressão indústria agrícola utilizada por ele em 1843 também é encontrada em escritos da metade do século XIX, apresentando a seguinte interpretação:

Percebe-se, em síntese, que a palavra indústria podia ser empregada, nos séculos XVIII e XIX, para designar diferentes situações e que esses usos não necessariamente correspondem ao significado contemporâneo do vocábulo. Por conseguinte, diante da multiplicidade de acepções de indústria, fica comprometido o esforço para se depurar um conceito único de industrialização, que acaba sendo confundido com o de crescimento industrial.

No Quadro 5, vê-se claramente como a indústria pastoril inicia-se juntamente com a atividade mineradora e vai perpassando todos os anos, como uma atividade econômica importante para a região, seja para os fazendeiros como também para os pequenos agricultores $^{26}$.

Contudo, o interessante ainda é perceber que a fábrica de tecidos ${ }^{27}$ surgiu no ano de 1886, antes da Proclamação da República e bem após a independência do país, quando o Brasil ainda era uma monarquia, marco das políticas econômicas dos reis que permitiram a implantação das indústrias no Brasil, proibidas no Período Colonial.

A fábrica têxtil União Lavrense foi instalada em uma fazenda às margens do Rio Grande, estratégia escolhida para fazer o transporte até a estação de Ribeirão Vermelho, que também funcionava bem próximo desse rio. Como ela era distante de uma vila, ao seu redor foi construída a estrutura de um povoado:

\footnotetext{
${ }^{26} \mathrm{O}$ setor agropecuário foi, durante a Monarquia e as primeiras décadas da República, o setor exportador de maior importância para a economia brasileira. Um indicador é a criação dos Campos de Demonstração, um estabelecimento federal com regulamentos no Diário Oficial do Estado de 10 de outubro de 1910 e que tinha como objetivo difundir entre os agricultores novas técnicas de produção que garantissem um aumento sem muito custo. A cidade de Lavras passou a ter um Campo de Demonstração a partir de 1912 (cf. PEREIRA, 2005, p. 400).

${ }^{27}$ Esse foi o primeiro ramo de produção industrial que se iniciou no Brasil, sendo que, para alguns historiadores, no país nunca deixou de existir uma produção manufatureira, mas também nunca houve um desenvolvimento industrial expressivo antes da década de 1870), como afirma Birchal (2004, p. 2): “As indústrias têxteis e de alimentos que foram a base do crescimento industrial brasileiro não surgiram até 1840 . $\mathrm{Na}$ verdade, não houve crescimento industrial significativo até a década de 1870".
} 
[...] possuía um porto de embarque e desembarque, cemitério, capela, energia elétrica própria e até mesmo cinema, no início do século. $\mathrm{Na}$ torre, vê-se um sino que era badalado diariamente às 21 horas, como um toque de recolher, e o silêncio era religiosamente respeitado. (NEGRÃO, 2004).

O poder nessa citação emerge sob uma perspectiva foucaultiana, sendo que a fábrica está situada num lugar isolado, mas não é cercado como os povoados da Idade Média, que tinham nos grandes muros a proteção garantida. Mas ela se fecha em si mesma, numa ordem que distribui os espaços e que deve ser respeitada, tendo a proteção vinda de um poder do alto, de onde estava o sino - provavelmente da capela -, ou seja, o sino como símbolo da voz de Deus, o poder religioso controlando as ações, como tão bem analisou Foucault:

A fábrica parece claramente um convento, uma fortaleza, uma cidade fechada; o guardião 'só abrirá as portas à entrada dos operários, e depois que houver soado o sino que anuncia o reinício do trabalho'; quinze minutos depois, ninguém mais terá o direito de entrar; no fim do dia, os chefes de oficina devem entregar as chaves ao guarda suíço da fábrica que então abre as portas. É porque, à medida que se concentram as forças de produção, o importante é tirar delas o máximo de vantagens e neutralizar seus inconvenientes (roubos, interrupção do trabalho, agitações e 'cabalas') [...]. (FOUCAULT, 2013, p. 137-138)

O controle dos corpos com o tocar do sino se dá no momento em que os operários desejariam festejar e relaxar após um exaustivo dia de trabalho na fábrica de tecidos. Gondra (2009, p. 175) especifica bem esse sentido:

Se temos aqui um aprofundamento a respeito da apropriação do corpo, a dimensão isotópica do poder disciplinar é retomada no item 'a arte das distribuições'. Para Foucault, a disciplina exige a cerca, a especificação de um lugar próprio, fechado em si mesmo para que possa funcionar no seu ótimo, com sua eficácia máxima. No entanto, o isolamento por si só não é suficiente para assegurar o bom funcionamento dos aparelhos disciplinares. Para ele, o espaço deve favorecer a localização imediata dos indivíduos, segundo a máxima, isto é, o princípio geral do reticulado, de cada indivíduo em seu lugar e, em cada lugar, um indivíduo. Trata-se do quadriculamento e da ideia de que o espaço para o bom funcionamento das disciplinas é sempre, no fundo, celular.

Neste contexto, há indicativos de que a ideia de modernização da sociedade no século XIX passou, primeiramente, pela infraestrutura ${ }^{28}$ econômica para depois se associar à escola como um dispositivo importante para a civilização das pessoas.

\footnotetext{
${ }^{28}$ Partiu-se de uma compreensão na contramão do que é apresentado por Veiga quando ela escreve sobre as análises de Norbert Elias à respeito da organização dos Estados Modernos e a modernização da sociedade, que "não passa pela infraestrutura econômica, mas por um processo de racionalização que afeta as mentalidades e o dispositivo social" (VEIGA, 2002, p. 96).
} 
Para Greive (2002), os indivíduos, desde o século XVI, evoluíram lentamente em seus comportamentos, em suas atitudes e valores de acordo com os valores cristãos, mantendo o que era próprio da natureza humana: um ser mesclado com atitudes ainda bárbaras. Com a criação dos Estados Nacionais e das monarquias, os reis passaram a ter maior controle sobre os súditos e, com o surgimento da burguesia, um comportamento mais civilizado ${ }^{29}$ se fez necessário:

Como nova e necessária feição de convívio social, difundiu-se um modelo de conduta pautado na racionalidade e no autocontrole sobre as emoções e afetos, como nítida diferenciação entre o que se podia fazer em público e o que se restringia ao âmbito privado. Essa noção contribuiu para ampliar a consciência e a autonomia dos indivíduos sobre si mesmos, mas também estabeleceu distinções mais acentuadas entre os autodenominados "civilizados", ${ }^{30}$ e os elementos das classes pobres, considerados embrutecidos e ignorantes. (VEIGA, 2007, p. 81)

Esses modelos culturais se espalharam pelo mundo, principalmente no final do século XIX; e no Brasil, com o movimento pró-republicano, surgem questões voltadas para a estruturação de uma nova organização da sociedade e da política, fundamentada nos moldes de uma sociedade republicana sob os símbolos modernos influenciados por conceitos liberais e positivistas, envolvendo intelectuais e políticos.

Veiga e Faria Filho (1997, p. 204) interpretam esse momento no Brasil, quando os projetos republicanos se preocupam em elevar o nível cultural de homens e mulheres brasileiros, buscando uma formação de pessoas mais civilizadas e educadas.

\section{Considerações finais}

Quando a República foi proclamada no Brasil, em 1889, a situação da educação pública era bastante precária no interior brasileiro. Especificamente na cidade de Lavras, ainda se podia perceber certo avanço, por causa da iniciativa do município, que tomou providências, independentemente do poder provincial, para zelar por suas escolas. Mas na imprensa encontram--se várias notícias de fechamento de escolas dada a falta de verba e,

\footnotetext{
${ }^{29}$ Não me refiro, neste trabalho, a outros campos do saber que contribuíram para a construção da ideologia acerca do civilizado, como a filosofia, por meio de filósofos que desenvolveram uma compreensão sobre a razão, o indivíduo e a sociedade desde o século XVI até o século XIX. Muitos desses pensamentos mais tarde foram denominados humanismo, liberalismo, iluminismo, romantismo, positivismo e marxismo (para maior aprofundamento sobre o tema, cf. VEIGA, 2007).

${ }^{30}$ A palavra entre aspas reporta aos escritos de Elias (1993, p. 18) quando ele dá sua interpretação ao surgimento da suavidade, da polidez e da civilização em estamentos que não eram somente os governados pela cristandade: "Aqui se criaram os modelos do intercâmbio social mais pacífico de que, em maior ou menor grau, todas as classes precisavam, depois da transformação da sociedade europeia ocorrida ao fim da Idade Média; aqui os hábitos mais rudes, os costumes mais soltos e desinibidos da sociedade medieval, com sua classe guerreira superior e o corolário de uma vida incerta e constantemente ameaçada, são 'suavizados', 'polidos' e 'civilizados'. A pressão da vida de corte, a disputa pelo favor do príncipe ou do 'grande' e depois, em termos mais gerais, a necessidade de distinguir-se dos outros e de lutar por oportunidades através de meios relativamente pacíficos (como a intriga e a diplomacia), impuseram uma tutela dos afetos, uma autodisciplina e um autocontrole, uma racionalidade distintiva de corte, que, no início, fez que o cortesão parecesse a seu opositor burguês do século XVIII, acima de tudo na Alemanha, mas também na Inglaterra, como o suprassumo do homem da razão."
} 
também, da não realização de uma reforma educacional que aplicasse modernos métodos pedagógicos ${ }^{31}$ difundidos por vários educadores internacionais ${ }^{32}$.

Para Veiga (2007, p. 237), o período compreendido entre 1889 e $1971^{33}$ representa uma época de muitas transformações históricas no Brasil. Além da abolição da escravatura, ocorrida em 1888, e com o início do regime republicano, inicia-se um processo de aumento tanto da urbanização e da população, quanto do crescimento industrial do país.

A reforma da instrução pública primária em 1906 no Estado de Minas Gerais pode ser considerada uma iniciativa no sentido de universalização da escola pública, bem como o início de um novo modelo de escola mais organizado e racional, com a criação dos grupos escolares.

O poder público municipal também se fez presente nas tramitações de instalação do Grupo Escolar de Lavras, representado por políticos fluentes ${ }^{34}$ da época e da comunidade que acompanhava a transformação das antigas escolas reunidas e/ou isoladas no agrupamento e surgimento de uma nova cultura escolar.

Esse novo modelo escolar foi considerado para a época o que de mais moderno se teve, tanto na construção dos prédios quanto na inovação pedagógica e curricular. Descortinase a partir daí um progresso que perpassaria a escola, responsável pela mudança de hábitos e de práticas culturais mais racionais e civilizatórias.

${ }^{31}$ No final do século XVIII, já haviam sido desenvolvidos alguns métodos que tiveram influências de pensamentos de alguns filósofos tais como Locke, Bacon, Hume, Rousseau, Rabelais, Comenius, entre outros, como o Método Intuitivo, que foi criado na Alemanha por Basedow, Campe e Pestalozzi. Por meio de um manual denominado Lições de coisas, o objetivo deveria ser estudado intuitivamente, ou seja, pelos sentidos e pela sua observação, sempre "partindo do particular para o geral ou, desconhecido o objeto, passava-se a conhecê-lo, indo do concreto para o abstrato". Outro método que substituiu o método Lancasteriano foi o Simultâneo, que, ao contrário da pedagogia de Joseph Lancaster, propunha um ensino coletivo para um grupo reduzido de alunos, de 40 ou até 60 estudantes, sendo o professor quem ensinava o conteúdo, não mais de maneira individual ou com a ajuda de monitores (PEREIRA, 2005, p. 31).

${ }^{32}$ Para Souza (1998, p. 36), a existência desses métodos não representou a sua aplicação ampla nas reformas educacionais realizadas posteriormente à Proclamação da República, pois o aspecto financeiro foi um fator determinante na sua execução, e a aplicação deles implicava uma reforma estrutural com um custo elevado, mesmo que sua configuração fosse importante para uma escola que se propunha como modelo: "O método, mais que a organização administrativa-pedagógica, foi ressaltado como configurador dessa escola modelar. Esse paradigma fundamentava-se numa nova organização cujo impacto e implicações foram obscurecidos pela relevância atribuída aos métodos de ensino modernizadores. Neste caso, o consumo e apropriação das ideias ocorreu por um duplo processo de incorporação e exclusão."

${ }^{33}$ Esta pesquisa compreende especificamente os anos de 1892 a 1942, propondo-se apresentar dados de desenvolvimento educacional, econômico, político e social bem próximo ao período demarcado por Veiga (2007), mas com um diferencial de inserir indicativos locais de crescimento nos campos da educação, da economia, da política e da sociedade.

${ }^{34}$ Entre resistências, tensões e interesses [...], Firmino Costa creditou a criação do Grupo Escolar a representantes da cidade, que ele não deixa explícito quem são, mas que, "não medindo sacrifícios, foram à Capital Mineira advogar seus interesses perante o governo." (FOLHA DE LAVRAS, 23 dez. 1906). A cidade de Lavras possuía, nessa época, alguns políticos de influência no cenário mineiro, tais como Francisco Sales, que fora presidente da província de Minas na chamada Primeira República (1902-1906) e, depois desse mandato, senador federal; seu irmão, Pedro Sales, presidente da Câmara Municipal de Lavras; e também Zoroastro Alvarenga, eleito deputado estadual no mesmo ano em que o Grupo Escolar foi inaugurado. Ao referir-se a uma possível disputa entre as cidades mineiras para possuírem Grupo Escolar, Faria Filho escreve que outras cidades eram preteridas ao requerê-lo, caracterizando a "importância e centralidade dos grupos escolares nas cidades mineiras" (FARIA FILHO, 2000, p. 46). Isso leva a crer que, se o movimento de afirmação dos Grupos Escolares precisou de alguns anos para se consolidar, essa disputa se fez presente desde os momentos iniciais da reforma do ensino de 1906. Tomando como exemplo a cidade de Lavras, cuja imprensa propagava a importância da reforma educacional, houve também influência política traduzida no poder de negociação de políticos da cidade perante o governo mineiro (Cf. PEREIRA, 2005, p. 52). 


\section{Referências}

BASTOS, Rodrigo Almeida. Regularidade e ordem das povoações mineiras do século XVIII. Revista do Instituto de Estudos Brasileiros da Universidade de São Paulo, São Paulo, n. 44, p. 27-54, fev. 2007. Disponível em: <http://www.revistas.usp.br/rieb/article/view/ 34561/37299>. Acesso em: 04 fev. 2014.

BINETTI, Saffo Testoni. Progresso. In: BOBBIO, Norberto (Org.). Dicionário de política. Brasília: EdUnB, 1995.

BIRCHAL, Sérgio de Oliveira. O empresário brasileiro: um estudo comparativo. 2004. Disponível em: 〈www.ceaee.ibmecmg.br/wp/wp11.pdf〉. Acesso em: 1. ${ }^{\circ}$ mar. 2018.

ELIAS, Norbert. O processo civilizador: formação do estado e civilização. Rio de Janeiro: Zahar, 1993. v. 2.

FOLHA DE LAVRAS. Lavras, 17 set. 1899.

FOLHA DE LAVRAS. Lavras, 30 nov. 1902.

FOLHA DE LAVRAS. Lavras, 1. jun. 1902.

FOLHA DE LAVRAS, Lavras, 7 dez. 1902.

FOUCAULT, Michel. Vigiar e punir: história da violência nas prisões. Petrópolis, RJ: Vozes. 2013.

GAMMON, Clara. Assim brilha a luz: a vida de Samuel R. Gammon. Lavras: Imprensa Gammon, 1959.

GONDRA, José Gonçalves. Tomar distância do poder. In: RAGO, Margareth; VEIGANETO, Alfredo. (Org.). Para uma vida não fascista. Belo Horizonte: Autêntica, 2009.

HEES, Felipe. A industrialização brasileira em perspectiva histórica. Em tempo de Histórias, Brasília, n. 18, p.100-131, jan./jul. 2011.

NEGRÃO, Eduardo Fernandes. Família Negrão. 2004. Disponível em: <http://pagfam.geneall.net/6331/pessoas.php?id=1131024>. Acesso em: 18 fev. 2013.

O CARACTER. Lavras, 27 jan. 1895.

PEREIRA, Jardel Costa. Grupo Escolar de Lavras: produzindo uma instituição modelar em Minas Gerais (1907-1905). 2005. 436 f. Dissertação (Mestrado em Educação) - Faculdade de Educação, Universidade Federal de Minas Gerais, 2005. Disponível em: <http://www.bibliotecadigital.ufmg.br/dspace/handle/1843/FAEC-858MHL>. Acesso em: 21 fev. 2018.

ROUSSEAU, Jean Jacques. Carta a D’Alembert. São Paulo: Ed. Unicamp, 1993.

ROSSI, Paolo. Naufrágios sem espectador: a ideia de progresso. São Paulo: Ed. Unesp, 2000.

SMITH, Adam. A riqueza das nações. São Paulo: Nova Cultural, 1985. 
SILVA, Alessandra Teixeira da; PAIVA, Patrícia Duarte de Oliveira. Do Romantismo à atualidade: Lavras, história de uma praça. Lavras: Ed. Universidade Federal de Lavras, 2008.

VEIGA, Cynthia Greive. A escolarização como projeto de civilização. Revista Brasileira de Educação, Rio de Janeiro, n. 21, p. 90-103, set./dez. 2002.

VEIGA, Cynthia Greive. História da educação. São Paulo: Ática, 2007.

VEIGA, Cynthia Greive; FARIA FILHO, Luciano Mendes de. Belo Horizonte: a escola e os processos educativos no movimento da cidade. Vária História, Belo Horizonte, n. 18, p. 203222, 1997.

VIDA ESCOLAR. Lavras, 15 jul. 1907.

VIDA ESCOLAR. Lavras, 1. ${ }^{\circ}$ set. 1907.

VIDA ESCOLAR. Lavras, 1. ${ }^{\circ}$ abr. 1908.

VIDA ESCOLAR. Lavras, 1. ${ }^{\circ}$ jul. 1908.

VIDA ESCOLAR. Lavras, 1. ${ }^{\circ}$ set. 1908.

VILELA, Márcio Salviano. A formação histórica dos Campos de Sant'Ana das Lavras do Funil. Lavras: Indi Gráfica, 2007. 